\title{
Prejudice emanating from non payment of pension interests due to what is contained in or omitted from divorce decrees
}

\section{Clement Marumoagae}

LLB LLM LLM Diploma in Insolvency Law and Practice

Senior Lecturer at the School of Law, University of the Witwatersrand

Practising Attorney, Marumoagae Attorneys

\section{SUMMARY \\ Nadeel voortspruitend uit die nie-betaal van pensioenbelange as gevolg van} wat ingesluit of uitgesluit word uit egskeidingsbevele

Hierdie artikel benadruk die praktiese uitdagings verbandhoudend met aftreefondse se weiering om dele van hul lede se pensioenbelang aan nielid eggenote uit te betaal na gelang van hoe egskeidingsbevele opgestel is. Daar word gedemonstreer dat nie-lid eggenote belas word met aansoek doen vir 'n wysigingsbevel om te voldoen aan sodanige fondse se onredelike eise om 'korrekte' egskeidingsbevele. Hierdie artikel voer 'n argument dat, sodra die pensioenbelang 'n bate geag word in ooreenstemming met artikel 7(7) van die Egskeidingswet, Wet 70 van 1979 , daar dan geen regverdiging is vir die fondse om te weier om die nielid se deel van die lid se pensioenbelang, soos ter datum van egskeiding, te betaal nie. Daar word verder geargumenteer dat die regsbelang wat die nie-lid eggenoot in die lid se pensioenbelang, verkry in terme van die partye se huweliksgoederebedeling, die betaling van sodanige belang in elk geval regverdig, omdat daar nie voldoen is aan die bepalings van die artikel 7(8) van die Egskeidingswet nie

\section{Introduction}

Section 7(7) of the Divorce Act $^{1}$ (hereinafter referred to as DA) provides a statutory mechanism which opens up the member spouse's pension interest to be split or shared when the member divorces. This section turns the pension interest which is ordinarily not a patrimonial asset in the marriage into an asset in the estate of the member spouse by deeming it as such for the purposes of divorce. Thereafter, section $7(8)$ of the DA empowers the court first to make an order that any portion of the member's pension interest be paid to the non-member spouse. Secondly, it empowers the court to instruct the registrar of the court to inform the retirement fund concerned to make such payment to the nonmember spouse as a result of the parties' divorce. Sections 7(7) and 7(8)

* I wish to thank the anonymous reviewers for their careful reading of this contribution and their insightful suggestions, which I believe have improved this paper. I nonetheless, take full responsibility for all the shortcomings of this paper.

170 of 1979

How to cite: Marumoagae 'Prejudice emanating from non payment of pension interests due to what is contained in or omitted from divorce decrees' 2018 De Jure 102-12 http://dx.doi.org/10.17159/2225-7160/2018/v51n1a7 
of the DA are applicable at the dissolution of all marriages entered into in community of property or out of community of property with the application of the accrual system in terms of the Matrimonial Property Act. $^{2}$ These provisions should be read in conjunction with various other pieces of legislation, including the Pension Funds $\mathrm{Act}^{3}$ (hereinafter referred to as PFA) which regulates different aspects of the South African retirement industry. ${ }^{4}$ Section 37D (4)(a) of the PFA provides for the so 'called clean break principle' by allowing non-member spouses of members of retirement funds regulated by this legislation to be able to claim their share of their member spouses' retirement benefits as at the date of divorce. In order to claim, non-member spouses need not wait for the accrual of such benefits based on any of the contingencies outlined in the rules of such retirement funds, which can be later on after the divorce. ${ }^{5}$ The clean break principle was subsequently translated to other retirement funds which are regulated by their own legislation. ${ }^{6}$ The judicial interpretation of sections $7(7)$ and $7(8)$ of the DA as well as section $37 \mathrm{D}(4)$ (a) of the PFA has been subject to controversy leading to inconsistent approaches by various divisions of the High Court. The major controversy related to whether or not the pension interest automatically forms part of the joint estate or accrual for the purposes of division when the parties divorce. This discussion has already received adequate academic attention and despite its relevance, it is nonetheless, beyond the scope of this paper. ${ }^{7}$

This paper focuses on a challenge that arises in practice relating to retirement funds tendencies of refusing to make payments of parts of members' pension interests to non-member spouses based on what is either contained in or omitted from divorce decrees. In particular, I demonstrate that retirement funds often reject divorce orders that do not precisely state their names or those that totally do not mention their names on the basis that such orders do not comply with section 7(8) of the DA. I proceed to demonstrate that this tendency is used to justify the contention that in order for retirement funds to make payment of portions of their members' pension interest to non-member spouses,

88 of 1984 .

24 of 1956

See Government Employees Pension Law 21 of 1996, Transnet Pension Fund Amendment Act 41 of 2000, South African Post Office SOC Ltd Amendment Act 38 of 2013, Post and Telecommunications Related Matters Act 44 of 1958, Temporary Employees Pension Fund Act 75 of 1979, and Associated Institutions Pension Fund Act 41 of 1963 and Social Assistance Act 13 of 2004 as well as the Income Tax Act 58 of 1962. Over the years there has been various amendments to all these statutes.

5 MC Marumoagae 'A Critical Discussion of a Pension Interest as an Asset in the Joint Estate of Parties Married in Community of Property' 20141 Speculum Juris 55-73 65.

6 Ngewu and Another v Post Office Retirement Fund and Others 20134 BCLR 421 (CC) and Wiese v Government Employees Pension Fund and Others 2012 6 BCLR 599 (CC).

7 Marumoagae 'Non-member's Entitlement to the Pension Interest of the Member's Pension Fund' 2014 PER 2488-2524. 
divorce decrees should specifically mention the names of retirement funds that should make such payment. This contention is examined with reference to the relevant provision of the PFA which not only provides for the naming of retirement funds in the decree of divorces but also the identification of such retirement funds thereon. It will be shown that retirement funds rely only on one aspect of the relevant provision and disregard the requirement relating to the identification of retirement funds in the divorce decrees to the detriment of non-member spouses. An argument is advanced that this prejudices non-member spouses who are forced to apply for the variation of divorce orders in order to reflect the names of retirement funds at great costs before they can be paid their portions of the member spouses' pension interests. It is further shown that this position justifies a view that in order for the non-member spouse to be paid the portion of the member spouse's pension interest, he or she must plead and pray for such an order in the pleadings.

In this paper, I start by illustrating how the Supreme Court of Appeal in 2016 interpreted sections 7(7)(a) and (8) of the DA. In particular, I demonstrate how this court challenged the thought that it is necessary to claim and pray for the pension interest in the divorce pleadings in order for the court to make an order in terms of section $7(8)$ of the DA. Secondly, I outline practical challenges experienced by non-member spouses as a result of retirement funds' rejection of divorce orders that are regarded as non-compliant with relevant statutory provisions. Finally, given the fact that majority of marriages are in community of property, I demonstrate that it is possible for retirement funds to make payment of the portions of their members' pension interests to the nonmember spouses when divorce decrees are silent on both the names of retirement funds and percentages that must be paid when parties are married in community of property. However, when parties are married out of community of property with the application of the accrual system, retirement funds will not be able to determine the percentage or amount that must be paid to the non-member spouse. The resolution of the latter issue is subject of my further research.

\section{Ndaba judgment}

On 4 November 2016, the Supreme Court of Appeal delivered judgement which sought to clarify the manner in which the law regulating pension interests in South Africa should be understood. ${ }^{8}$ Petse JA writing for the majority, started by highlighting that there are several conflicting decisions of various divisions of the High Court regarding the interpretation of sections 7(7)(a) and (8) of the DA. ${ }^{9}$ After reviewing some of these conflicting judgements, he then authoritatively held that:

$8 \quad$ Ndaba v Ndaba 2017 (1) SA 342 (SCA).

9 Idem at par 2. 
[f]irst, s 7(7)(a) is self-contained and not made subject to s 7(8). It deems a pension interest to be part of the joint estate for the limited purpose of determining the patrimonial benefits to which the parties are entitled as at the date of their divorce. The entitlement of the non-member spouse to a share of the member spouse's pension interest as defined in the Act is not dependant on s 7(8). To my mind, it would be inimical to the scheme and purpose of $\mathrm{s} 7(7)(a)$ if it only applies if the court granting a divorce makes a declaration that in the determination of the patrimonial benefits to which the parties to a divorce action may be entitled, the pension interest of a party shall be deemed to be part of his or her assets. The grant of such a declaration would amount to no more than simply echoing what s 7(7)(a) decrees. For the same reasons it was not necessary for the parties in this case, to mention in their settlement agreement what was obvious, namely that their respective pension interests were part of the joint assets which they had agreed, would be shared equally between them. ${ }^{10}$

This is arguably the most important paragraph in Ndaba and also constitutes the point of departure for the argument that I am advancing in this paper. Petse JA's remarks were clearly directed to the specific facts that he was confronted with, wherein the parties' settlement agreement which was made an order of court was silent on how the pension interest ought to be dealt with. ${ }^{11}$ Petse JA provided clarity in relation to the role of section 7(7)(a) and section 7(8) of the DA in the broader scheme of disputes relating to pension interests in South Africa. First, he correctly demonstrated that the operation of section 7(7)(a) of the DA is triggered only when the member spouse is divorcing and at that date renders his or her pension interest to be part of his estate. This enables the nonmember spouse to be able to claim part of that pension interest if the parties are married in community of property, or at the very least, for the value of the pension interest to be taken into account when the accrual is calculated if the parties are married out of community of property subject to the accrual system. The parties' marital regime entitles the non-member spouse once the pension interest has been deemed as an asset in the member spouse's estate to claim a portion thereto. Petse JA's reasoning clearly indicates that such an entitlement to claim the pension interest is not dependent on the court acting in terms of section 7(8) of the DA declaring that the non-member spouse should receive a particular portion of the member spouse's pension interest. On the facts of this case, Petse JA was convinced that it was obvious that once the pension interest had been deemed as an asset it also became part of the parties' joint estate and as part of the joint estate there was no need for the appellant to go out of her way to mention that it was part of the joint estate and that it would be shared equally between them. This means that once the pension interest is regarded as part of the joint estate pursuant to the deeming provisions, then it follows that the appellant

\section{Idem at par 25.}

11 Idem at par 2 and 5. The court further stated that " $[t]$ he divorce order granted by the trial court incorporated a provision that '... the deed of the settlement between the parties ... [annexed thereto] is made an order of the court.' The parties' deed of settlement in turn provided, inter alia, that their joint estate would be divided equally between them'. 
derived a right to share the portion of pension interest. It can be argued that Petse JA's approach supports a contention that it is not compulsory when parties are married in community of property to specifically plead a case for a pension interest in their pleadings. In that once the pension interest has been deemed to be an asset in the member spouse's estate, the fact that the parties are married in community of property will make the deemed asset part of the parties' joint estate.

Petse JA went further and endorsed academic view that criticised cases that 'espouse the proposition that for the pension interest of a member's spouse to form part of the joint estate upon divorce, it is necessary that it be claimed by the non-member spouse in his or her summons or counter-claim'. ${ }^{12}$ It is submitted that these obiter remarks by Petse JA justifies an argument that I am advancing in this paper that there is no need to plead and pray for a pension interest in order for retirement funds to pay portions of the member spouses pension interests to non-member spouses. In actual fact, Petse JA unequivocally held that " $[t]$ he joint estate in this case must necessarily include the pension interest of either party as contemplated in s 7(7)(a) of the Act'. ${ }^{13}$ Once the pension interest has been deemed to be part of the member's pension interest, it is difficult to understand why in order for the nonmember spouse to receive a portion thereto, he or she must first make an averment in his or her pleading and pray that the court order that he or she should be paid his or her portion. The current legal position is indeed that the court must make an order directing the retirement fund to pay any part of the pension interest to the non-member spouse in terms of section $7(8)$ of the DA. Without such court orders, retirement funds in practice generally refuse to make payments of portions of their members' pension interests to non-member spouses. There is a need to reflect on the soundness of this legal position in light of Petse JA's interpretation in Ndaba. Such a reflection should not amount to an abstract academic debate but should be approached from a practical point of view in light of the experiences of non-member spouses when their divorce decrees are rejected by retirement funds, which I will do in the next section.

Petse JA's approach attracted a discussion by two pension law legal practitioners. First, Marumoagae argued that based on Petse JA's judgment in Ndaba he hoped 'that retirement funds ... will no longer burden divorce litigants with the duty to plead and pray for pension interest in order for divorce decrees to order retirement funds to pay pension interests to non-member spouses'. ${ }^{4}$ This elicited a reply from Jeram, who without referring to any part or page of Marumoagae's article argued that 'Marumoagae ... concludes that the court ruled that it is not necessary for the pension fund to be identified and ordered to pay the

12 Idem at par 28

13 Idem at par 34

14 Marumoagae 'Pension interest - is there a need to plead a claim? (2017) Jun De Rebus 39. 
benefit in order for such a fund to pay the non-member spouse. It is this conclusion that I respectfully disagree with, as in my view, this was not the court's ruling, nor does it reflect the current position in law'. ${ }^{15}$ Marumoagae replied to Jeram and argued that Jeram misinterpreted his earlier argument in that he did not argue that Ndaba ruled that it is not necessary for the pension fund to be identified and ordered to pay the member's portion of the member's pension interest in accordance with section $7(8)$ of the DA. ${ }^{16}$

In his reply, Marumoagae clarified that based on paragraph 52 of Petse's judgement in Ndaba which is quoted above, his argument was 'that where there is no settlement agreement, it is then equally not necessary for the parties to plead and pray for a joint estate, particularly when they are married in community of property' ${ }^{17}$ In other words, the non-member spouse should not be at the mercy of the court to declare that he or she is entitled to receive a portion of the pension interest because section $7(7)$ of the DA in conjunction with the marriage in community of property already enables the sharing of the pension interest. The sharing of the pension interest where parties are married in community of property is a statutory consequence based on the parties' marital regime which is not dependent on judicial determination. Thus, once it has been shown that the parties' marital regime enables sharing and the pension interest has been deemed to be part of the member's estate, the court does not have discretion to refuse to grant an order that the non-member spouse should be paid his or her portion of the member spouse's pension interest. The divorce courts' only discretion relate to the actual percentages or amounts that must be paid to non-member spouses, the determination of which would depend on the facts of the cases.

In Ndaba, Makgoka AJA wrote a dissenting judgment which has been endorsed by Ramabulana who referred to it as a well-reasoned judgment. ${ }^{18}$ Unfortunately, I do not share the same sentiments. Makgoka AJA generally agreed with Petse JA's exposition of the law but disagreed with the application thereof on the particular facts of the case. This led

15 Marumoagae 'Is it still necessary to obtain a court order against a fund? A rebuttal'(2017) Jun De Rebus 24.

16 Marumoagae 'Enforceable orders against retirement funds after divorce: A rejoinder' (2017) Jun De Rebus 35.

17 Ibid.

18 'Ndaba v Ndaba - reconciling the irreconcilable' (2017) Jun De Rebus 51. Ramabulana opines that 'The finding of the majority is not as flawless as it could have been. Even if the majority disagreed with the minority on the incorrect classification of pension interest as neither an immovable nor a movable asset, there was nothing preventing the parties from including the third heading of incorporeals under which pension interest could be counted. Thus, the reasoning of the majority in this aspect contradicts the maxim expressio unius est exclusio alterius and confirms the suggestion by the minority that the majority may have adopted a sympathy approach, which under the circumstances was woefully inappropriate as the judgment on this issue was still unenforceable against the fund? 
him to take a different interpretative route which sought to weigh the settlement agreement with what was contained in the appellant's prayers in her particulars of claim. I am of the view, with respect, that this was a misdirection. In my view, Makgoka AJA ought to have dealt with the settlement agreement on its own without any reference to the prayers in the summons because the settlement agreement was an actual order of the trial court, not the prayers in the particulars of claim. It is common in practice when parties litigate to plead and pray for a variety of things but later settle on completely different things. For instance, a plaintiff may pray for forfeiture of patrimonial benefits in terms of section 9(1) of the DA but eventual settle on the division of the joint estate. It cannot be that if the matter is appealed to a higher court, then such a court wishes to hold him or her on how his or her prayers were crafted in his or her pleadings. It is submitted that Makgoka AJA ought to have confined his analysis to the settlement agreement which was eventually made an order of court in order to determine whether or not such settlement agreement could be interpreted to include the parties' pension interest.

It was an uncontested fact in Ndaba that there was a settlement agreement which was silent on the pension interest. In other words, there was no specific clause in the settlement agreement which the trial court made an order of court wherein parties expressly waived their rights to each other's' pension interest. Makgoka AJA was persuaded by the respondent's argument that the appellant in her pleadings renounced her claim towards the respondent's pension interest. ${ }^{19}$ This led Makgoka AJA to express a view that the parties 'agreed to exclude their respective pension interests from the division of their joint estate,20 without pointing to a particular clause in the parties' settlement agreement. In his judgement, Makgoka AJA highlighted the fact that the appellant's combined summons expressly excluded a claim for the pension interest. ${ }^{21}$ Makgoka AJA appears to have interpreted this fact as having a direct link to the settlement agreement. In that, because the appellant had excluded the pension interest in her prayer which was inserted in her particulars of claim, that was an illustration of her frame of mind at the time she concluded the settlement agreement and was thus consistent by not including her claim of the pension interest in the settlement agreement. It is submitted that this reasoning is not sound in law.

Makgoka AJA proceeded to deal with the subheadings of the settlement agreement and contended first that anything which did not

19 See Ndaba supra n8 at par 5.

20 Idem at par 39

21 Idem at par 47. The justification for this was that '... was assisted by one $\mathrm{Mr}$ Sentsho, whom she believed to be an attorney (who later turned out not to be). According to the appellant, she had indicated to Mr Sentsho that she wished to share in the respondent's pension interest. Mr Sentsho informed to her that if she included a prayer for sharing in the respondent's pension interest, it would bring about a lot of administrative difficulties'. 
fall within the identified movable and immovable assets was not included in the division of the joint estate. Secondly that '[p]ension interests are

neither immovable nor moveable property'. ${ }^{22}$ He reasoned that 'traditionally, the pension interests did not form part of the assets of the parties. Only by special legislative enactment in the form of $\mathrm{s} 7(7)(\mathrm{a})$, were they deemed so'. ${ }^{23}$ He further justified his approach by stating that '[t]he situation would have been entirely different had there been no heading. In that event, the clause providing for the equal division of the joint estate would have constituted a so-called blanket division. That would have brought the pension interests within the purview and reach of the deeming provisions of s 7(7) of the Divorce Act'. ${ }^{24}$ In other words, if there are no headings in the settlement agreement and provision for a pension interest is not specifically made in therein, a pension interest can nonetheless, still be read into that settlement agreement. Thus, the headings of the settlement agreement and the items listed thereunder indicated that the pension interest was not made part of the settlement agreement. I do not agree with this approach. It is submitted that Makgoha AJA's reasoning is unsound for the reasons given by Petse JA as follows:

Old Mutual Life Assurance approved of the description of a pension interest in the South African Law Commission's Reports dealing with the division of pension benefits on divorce in Project 41 (March 1995) and the sharing of pension benefits in Project 112 (June 1999), namely, that a 'pension interest' is a notional asset which 'simply establishes a method of ascertaining the value of the 'interest' of the member of the pension or retirement annuity fund as accumulated up to the date of the divorce'. This notional asset 'is added to all the other assets of the party concerned in order to determine the extent of the other party's claim to a part of the first-mentioned party's assets'... However, sight must not be lost of the fact that the parties in this case were married in community of property. Consequently, one of the invariable consequences of such a marriage is that, subject to a few exceptions not here relevant, the spouses became co-owners in undivided and indivisible half-shares of all the assets acquired during the subsistence of their marriage. And, absent a forfeiture of benefits under s 9(1) of the Act or an express agreement between the parties to the contrary, each spouse is entitled to a half-share of the joint estate - whatever it entails. ${ }^{25}$

Petse JA proceeded to correctly hold that '[i]t therefore goes without saying that the parties' entitlement to each other's pension interests,

\footnotetext{
22 Idem at par 51.

23 Ibid.

24 Idem par 52.

25 Ndaba supra n8 at par 33. See also Old Mutual Life Assurance Company (SA) Ltd and Another v Swemmer 20045 SA 373 (SCA).

26 Idem at par 35, he further held that '[b]y its very nature, movable property comprises both corporeal and incorporeal things. According to the learned authors of Wille's Principles of South African Law typical examples of incorporeal movables, inter alia, include real rights such as a pledge, notarial bond, mortgage bond, or any rights in personam that are connected with the transfer of movable property from one person to
} 
which can be satisfied by a money payment, falls squarely within the rubric of movables'. ${ }^{26}$ Makgoka AJA further accepted that the appellant was not properly represented, the respondent's attorneys drafted the settlement without the parties negotiating the terms thereto, and that " $[\mathrm{i}] \mathrm{f}$ the appellant had negotiated with them for the inclusion of the pension interests in the settlement agreement, she would surely have enquired about its non-inclusion, on being presented with the settlement agreement'. ${ }^{27}$ He then concluded that '[t]he drafters of the settlement agreement were therefore entitled to draft the settlement agreement on the basis of the pleadings, unless the appellant had conveyed to them a contrary attitude with regard to the pension interests'. 28 It cannot be doubted that lawyers generally draft legal documents to benefit their clients and would push for their clients' desired outcomes in legal negotiations. Makgoka AJA approach made it impossible for him to address the entitlement of the appellant to the portion of the respondent's pension interest. In particular, he rushed to exclude the pension interest from the settlement agreement without any particular clause in the settlement agreement making provision for such exclusion. As such, his analysis could not lead him to engage Petse JA's sound reasoning that, it was not necessary for the appellant to mention in the settlement agreement that the pension interest fell within the joint estate and could be shared equally. ${ }^{29}$ Thus, he missed an opportunity to reflect on the implication of Petse JA's approach and how it ought to be understood in the broader context of divorce litigation. Had he engaged Petse JA in this regard, he would have expressed a view as to whether Petse JA's remarks were confined to the fact of the case or should be understood as advancing a view that there is no need generally to plead and pray for pension interests when parties are married in community of property. In other words, Makgoka AJA's approach made it impossible for him to express a view on whether a non-member spouse was obliged to pray and plead for a pension interest in order for the court to make an order directing a retirement fund to pay a portion of the member's pension interest to the non-member spouse.

\section{Payment to non-member spouse}

\section{Prejudice suffered by non-member spouses}

Section 7(8) of the DA is an effective practical tool that retirement funds use to frustrate non-member spouses when they claim parts of their member spouses' pension interests upon divorce. If an order has not been made in accordance with section $7(8)$ of the DA directing

another or which can be satisfied by a money payment'. See also Marumoagae 'The law regarding pension interest in South Africa has been settled! Or has it? With reference to Ndaba $v$ Ndaba (600/2015) [2016] ZASCA 162' (2017) 1 PER 1-22 at 13.

$27 \quad$ Ndaba supra $\mathrm{n} 8$ at par 59 and 65.

28 Idem at par 59.

29 Ndaba supra n8 par 28. 
retirement funds to make such payment, no payment will be made. Retirement funds also refuse to make payment when divorce orders have been made in accordance with section 7(8) of the DA but the names of such retirement funds have either been incorrectly spelt therein or have not been inserted. Retirement fund's strict approach to divorce decrees which they view as not being compliant with section 7(8) of the DA prejudices non-member spouses. This strict approach negatively affects litigants who are instituting divorce proceedings either on their own or with the assistance of legal practitioners who lack the necessary expertise in this area of law. In most 'do it yourself' divorces wherein the instituting party will be given a proforma divorce summons to fill out for themselves or with the assistance of the Registrar of the court, chances of failing to properly make out a case for a pension interest remains high and can be disastrous leading to such a party not being able to claim his or her share of the member spouse's pension interest. It could not have been the intention of the Legislature for legally unassisted or poorly assisted divorce litigants to be prejudiced by the requirement that they must ensure that the names of retirement funds are stated in their divorce decrees. It is worth noting that the court will only be able to state the name of the retirement fund on the divorce decree when a proper averment has been made in relation thereto in the pleadings and a prayer reflecting a pension interest is clearly reflected thereon. It is unfortunate however, that most legally unrepresented litigants are not able to properly plead and pray for a pension interest. In practice however, the Registrars of courts do make an effort to insert the relevant information in the proforma divorce forms that are usually used as 'fill in the missing information' summons to assist legally unrepresented divorce litigants. However, this is a highly technical area of family law which requires adequate legal training and assistance from even an experienced Registrar of court who does not have adequate knowledge of pension law may be detrimental to the pension interest claim of the legally unrepresented litigant.

The retirement funds' strict approach indicates the importance of knowing which retirement fund the member spouse is a member of, in order to ensure that a claim in the pleadings is made for the payment of a specified amount or percentage from a particular retirement fund. However, in practice, it is not always easy for lawyers generally and nonmember spouses in particular to find out which retirement funds' member spouses are contributing to. It is also difficult to find out the relevant retirement fund from the employer because of the alleged respect for privacy and confidentiality rights of member spouses by employers. Thus, non-member spouses are likely to institute divorce proceedings either without proper names of relevant retirement funds or at the very least merely stating general averment that the other party is a member of a retirement fund and the non-member spouse is entitled to a particular percentage thereto. If the member spouse attains legal representation, the non-member spouse might be lucky if in the member spouses' defending pleadings there is reference to the correct retirement 
fund. Unfortunately, this does not often take place in practice and nonmember spouses after the institution of divorce proceedings are forced to make interlocutory applications to compel the disclosure of correct retirement fund names at great expenses. This however, is not the luxury that is open to unrepresented non-member spouses who end up with divorce decrees that are likely to be rejected by retirement funds. Once divorce orders are rejected by retirement funds, non-member spouses are forced to approach courts to request variation of such orders. Such non-member spouses would be forced to seek legal advice at great costs to get the order to comply with section 7(8) of the DA as demanded by his or her member spouse's retirement fund.

It is important however, to note that there may be reasons behind retirement funds strict interpretation of the relevant provisions. The members of the board of management of retirement funds have a duty to uphold the rules of their retirement funds and all applicable laws. If indeed, there is a rule in the retirement fund rules that stipulates that payment will only be made to the non-member spouse once a court order directing the fund to pay has been received, such a rule will be followed to the latter by the fund. It appears also that the boards of retirement funds are also attempting to play it safe in that if their member was in future to challenge their decision to pay a portion of his or her pension fund to his or her former non-member spouse, they can defend themselves on the basis that they merely complained with a valid court order. I am nonetheless, of the view that given the fact that boards of retirement funds are able to act on advice of service providers such as their contracted firm of attorneys, they should receive legal advice on the interpretation of the cases discussed in this paper which appears to suggest that payment can be made notwithstanding, the fact that the court order did not mention the name of the fund. In particular, retirement funds regulated by the PFA ought to obtain legal advice on the proper construction of section 37D (4)(a)(i)(aa) of the PFA which will be discussed in the next section.

\section{Naming or identifying the retirement fund}

Regional Magistrates Courts in particular, are inundated with applications to vary divorce decrees in order to insert correct retirement fund names, more particularly where the parties were representing themselves or received poor legal representation. ${ }^{30}$ Because of the possibility of retirement funds refusing to pay parts of their members' retirement benefits upon divorce to the non-member spouses due to either their names not being reflected on the divorce decree or incorrectly spelt, this lead to the justification of an unfortunate contention that in order to ensure payment, it is important that a proper case for the payment of pension interest is made on the divorce pleadings. In that this will lead to the naming of the retirement fund on the divorce decree. Over and above section 7(8) of the DA, retirement funds which are regulated by the PFA rely on section 37D (4)(a)(i)(aa) of the PFA to refuse to pay portions of their members' pension interest to the non-member spouses on divorce. 
Section 37D (4)(a)(i)(aa) of the PFA provides that '... on the written submission of the court order by the non-member spouse [pension interest] must be deducted by the pension fund or pension funds named in or identifiable from the decree'. This provision clearly requires the non-member spouse to submit a divorce decree which either names or identifies the retirement fund which must make payment of the pension interest.

The statutory provisions regulating pension interests in South Africa are not easy to understand and to fully comply with in practice. Divorce litigants and legal practitioners often fall victim to non-compliance with the relevant provision which lead to non-member spouses' claim not being paid by retirement funds. The Pension Funds Adjudicator in Dosson $v$ Cape Municipal Pension Fund observed that:

The many complaints before this tribunal indicate that the pension funds are frequently incorrectly cited, or not mentioned by name at all, although they can usually be identified from context. In the circumstances where the fund is clearly identifiable, although not named, it seems unduly onerous to require a party whose claim has fallen due to make formal application for rectification of the divorce order. ${ }^{31}$

It is submitted that it does not make sense for a retirement fund to refuse to pay the non-member spouse's share of his or her member spouse's pension interest when such a fund despite the deficiencies on the divorce decree has nonetheless, established that the member spouse concerned is its member. It is undesirable for retirement funds to continue to insist that their names should be properly reflected on the divorce decrees in order for payment to be made. Initially, the office of the Pension Funds Adjudicator issued determinations which had the effect that if the settlement agreement or the court order does not refer to the pension interest and does not mention the retirement fund's name, the divorce decree will not bind the retirement fund and will only be binding as between the spouses. ${ }^{32}$ This was the basis within which retirement funds further justified refusing to pay parts of their members' pension interests

30 See Barnard $v$ Municipal Gratuity Fund [2009] 2 BPLR 143 (PFA) para 41, where the Pension Funds Adjudicator observed that 'many complaints before this tribunal indicate that pension funds are frequently incorrectly cited, or not mentioned by name at all, even though they can be identified from the context. Further, many of the complaints before this tribunal involve people who are not legally qualified to understand the requirement that a Fund should be named clearly in the decree of divorce. It also happens that people who are legally qualified sometimes fail to understand and comply with the requirement relating to the naming of a fund in a divorce order. Thus, it is unduly onerous to require a party whose claim has fallen due to make a formal application for rectification of the divorce order even in circumstances where the fund is identifiable from the facts or circumstances'.

3120091 BPLR 12 (PFA) par 5.13.

32 Ibid. 
to non-member spouses. ${ }^{33}$ In 2009, the Pension Funds Adjudicator adopted a different approach in Barnard $v$ Municipal Gratuity Fund. ${ }^{34}$ In realising the injustices of allowing retirement funds to refuse to pay portions of their member's pension interests based on some or other legal technicality, the Adjudicator observed that:

... many of the complaints before this tribunal involve people who are not legally qualified to understand the requirement that a fund should be named clearly in the decree of divorce. It also happens that people who are legally qualified sometimes fail to understand and comply with the requirement relating to the naming of a fund in a divorce order. Thus, it is unduly onerous to require a party whose claim has fallen due to make a formal application for rectification of the divorce order even in circumstances where the fund is identifiable from the facts or circumstances. ${ }^{35}$

The office of the Pension Funds Adjudicator is a special pension tribunal that has been established under the $\mathrm{PFA}^{36}$ to dispose of complaints lodged under this Act in a procedurally fair, economical and expeditious manner. ${ }^{37}$ The accessibility of this tribunal led to the multiplicity of complaints being made which enabled the Pension Funds Adjudicator to appreciate the burden placed on non-member spouses by retirement funds tendencies to strictly require that their names should be precisely stated on divorce decrees. In particular, the Pension Funds Adjudicator observed that:

It is further clear that the requirement that a fund should be named in the order tends to be costly and time consuming and could result in financial prejudices to the non-member spouse. This is due to the fact that a Complainant has to request an amendment of a divorce order if the fund concerned is not named clearly in the order. This is time-consuming and costly as the Complainant has to pay attorneys in order to rectify the divorce order and he/she must re-lodge a new complaint which clearly states the name of the fund involved. Further, a Complainant's rights to his/her benefit in a fund will be prejudiced by the delay as a result of a technical requirement relating to the naming of a fund. ${ }^{38}$

33 Ibid. See also Kapot v Liberty Group Limited PFA/WE/34972/2009/TN para 5.3 where it was determined that " $[\mathrm{t}]$ he divorce order is silent about the payment of pension interest by the respondent, or any other fund, to the complainant. It is also evident from the order that no fund is identified or identifiable in it, so it is impossible for the respondent to pay pension interest to the complainant because the order does not comply with the requirements of section $37 \mathrm{D}(4)(\mathrm{a})(\mathrm{i})(\mathrm{aa})$ of the Act. Therefore, without an order to the effect that a fund administered by the respondent must pay pension interest to the complainant, it cannot be compelled to do so'. See also Areias v Momentum Retirement Annuity Fund and Another 20131 BPLR 23 (PFA) par 5.5-5.6 and Budhoo v Sasol Pension Fund PFA/GA/37937/2009/ LPM par 5.8 .

3420092 BPLR 143 (PFA).

35 Idem at par 41

36 Section $30 \mathrm{~B}$ of the PFA.

37 Section 30D of the PFA

38 Barnard supra n34 at par 42. 
The Pension Funds Adjudicator was not starting a textbook academic discussion of the plight of non-member spouses but was reflecting on the true practical challenge that non-member spouses often after receiving divorce decrees are placed in by retirement funds. Retirement funds even when they have determined that ultimately they will have to pay, they nonetheless, raise legal technicalities that not only delay payment to non-member spouses but also financial burden them. This is as a result of retirement funds regulated by the PFA relying only on the first part of the requirement laid out in section 37D (4)(a)(i)(aa) of the PFA. They rely on the part that requires retirement funds to be named in divorce decrees. First, retirement funds interpret the requirement that their names must be named in the divorce decrees strictly. In that, divorce decrees should precisely state their registered names as they appear in their official documents, hence any deviation would be regarded as contrary to what the PFA provides for. For instance, I was once forced to apply for a variation order for my client's divorce decree which was rejected by the retirement fund because it stated 'provident fund' instead of a 'pension fund'. I had to request the court to change the name 'provident' and replace it with 'pension' in the divorce decree. Secondly, most if not all retirement funds that are regulated by the PFA disregards the requirement that the retirement fund concerned must be identifiable from the divorce decree. This requirement has not yet received academic and judicial interpretation and it is not exactly clear what it practically entails. It is not easy to think about ways in which the retirement fund could be identifiable from the divorce decree other than by stating it thereto.

Nonetheless, an argument can be made that even where the name of the relevant retirement fund was not stated in the divorce decree leading to the court not to make any order in terms of section 7(8) of the DA, it is nonetheless, possible at the very least to still identify the relevant retirement fund from the divorce decree. It is submitted that the name of the member spouse that appears on the decree of divorce with identity numbers which some magistrates and judges at times insert in divorce orders can be a viable means of identifying the relevant retirement fund. If one of the parties is a member of a retirement fund as a matter of fact, then his or her name and identity number is linked to a particular retirement fund. Thus, once an order has been granted and for example the non-member spouse approaches the member spouse's employer with the order and he or she is directed to the relevant fund, then the relevant retirement fund would have been identified. In other words, such a retirement fund was identifiable from the divorce decree through its own member's name and identity number which was reflected thereon. ${ }^{39}$

$39 M v M[2015] 2$ All SA 495 (FB) para 22 where the court held that '[w]here a settlement agreement provides for a blanket division of a joint estate or a court order orders a blanket division of a joint estate, all pension funds to which any of the spouses belong and had an interest in at the date of 
It is further submitted that the trade of the member spouse whose name appears on the divorce decree would also lead to the identification of the relevant fund which the non-member spouse should claim from. For instance, most public employees such as teachers, nurses and policemen are members of the Government Employees Pension Fund. However, there are private teachers and nurses who are not contributing to the Government Employees Pension Fund but to private retirement funds that their employers are associated with. Under such circumstances, once an order is granted, the employer may direct the non-member spouse to the relevant retirement fund. Employees of public enterprises such as Eskom are also contributing to retirement funds established specifically for such parastatals. Perhaps in future we may receive judicial guidance on how to interpret the requirement relating to identifying a retirement fund from the decree of divorce where there is no information that directly points to any retirement fund. The Pension Funds Adjudicator has interpreted section 37D (4)(a)(aa) of the PFA in Barnard $v$ Municipal Gratuity Fund as follows:

Having regard to the fact that the word 'identifiable' is not defined in the Act, its ordinary, literal and grammatical meaning should be given effect to in order to ascertain the intention of the Legislature. The ordinary and literal meaning of the word 'identifiable' means something that can be proved or is recognisable ... . Therefore, in order to prove something or recognise something some form of exercise or conduct or act needs to be carried out in order to prove or recognise the fund in question. The question that follows is what kind of conduct or act needs to be carried out in order to identify a fund from a divorce order. It is clear that a factual inquiry or a reasonable investigation has to be conducted in order to identify [the retirement] fund from an order. The intention of the Legislature in using a broad word like 'identifiable' from the divorce decree indicates that some form of investigation needs to be carried out in order to identify or prove or recognise a fund. Thus, in the event of an omission to name a fund or failure to clearly name a fund from a decree of divorce the question is whether a fund can be identifiable or be recognised after a reasonable investigation. ${ }^{40}$

It is submitted that the Pension Funds Adjudicator's interpretation is not necessarily useful in as far as identifying the relevant fund directly from the divorce decree is concerned. It does however, provide guidance on what should be done once the non-member spouse has somehow figured out the non-member spouses' retirement fund. Once the retirement fund has been issued with the divorce decree, in terms of the Pension Funds Adjudicator interpretation, there must be some form of investigation to determine whether the person stated on the divorce decree is indeed a member of the fund concerned. This might take the form of looking into the retirement fund records to determine if any of the persons mentioned on the divorce decree is the member of the fund. The first step of the investigation may be to enquire from the employer as to which retirement fund the employee who appears in the divorce decree belongs. ${ }^{41}$ Should such information be provided, the second step would be to approach the retirement fund or its administrator. That in my view, would constitute the reasonable investigation as contemplated by the 
Pension Funds Adjudicator. In other words, upon receipt of the decree of divorce, the retirement fund should take initiative to determine if the person against whom a claim for a portion of the pension interest is made is a contributing member to the fund. Once such reasonable investigation has been conducted and it is clear that the person named on the divorce decree is the member of the fund, the fund would have been properly identified and thus liable to pay the non-member spouse's portion of its member's pension interest. Also, if after the divorce, the non-member spouse through his or her own initiative is able to locate the correct retirement fund to which the member spouse belongs to, then such a retirement fund on the basis of section 37D (4)(a)(aa) of the PFA, would have been identified.

There is no similar provision that requires the name of the retirement fund to be named or at the very least to be identifiable in other pension law related statutes that established and regulates other retirement funds such as the Government Employees Pension Fund. ${ }^{42}$ These retirement funds often refuse to make payment to non-member spouses directly on the basis of section 7(8) of the Divorce Act. ${ }^{43}$ While the Adjudicator's determinations do not set precedent and are by and large directed at retirement funds regulated by the PFA, nonetheless, her remarks in Barnard are highly persuasive. It is submitted therefore that there is a need for all retirement funds when they have been identified as retirement funds which are affected by divorce decrees presented to them, after reasonable investigation and satisfying themselves of the

divorce are involved, in the sense that all such pension interests are deemed to be part of the joint estate. It then appears to be clear that all the pension funds involved as aforesaid are identifiable from the decree of divorce since the only question is whether the spouses were members of and had a pension interest at the date of divorce. Strictly speaking it would then not even be necessary to enter a specific name of a pension fund in a court order'

40 Barnard supra n34 at para 47. The Adjudicator relying on S v Toms; S v Bruce 19902 SA 802 (AD) at 807H-808A where it was stated that "[t]he primary rule in the construction of statutory provisions is to ascertain the intention of the Legislature. One does so by attributing to the words of a statute their ordinary, literal, grammatical meaning. Where the language of a statute, so viewed, is clear and unambiguous effect must be given thereto, unless to do so would lead to absurdity so glaring that it could never have been contemplated by the Legislature, or where it would lead to a result contrary to the intention of the Legislature', stated that ' $[\mathrm{t}]$ he questions that follow is what is identifiable, what is required in order to identify a fund from a decree of divorce and what is the Legislature's intention in this regard. It is trite law that this tribunal similarly to a court of law has a duty to interpret an Act of Parliament so as to give effect to its intention' (par 45).

41 In practice, different employers react differently to such enquiries. While other may provide the required information, others, will simply say that they are bound by confidentiality rules from disclosing such information.

42 See for instance the Government Employees Pension Law Proc 21 of 1996 and Transnet Pension Fund Act 621990.

43 See generally Government Employees Pension Fund $v$ Naidoo and Another [2006] 3 All SA 332 (SCA). 
membership of those identified thereto to make payments to nonmember spouses.

\section{Specifying a percentage or amount in the divorce decree}

In Ndaba, Petse JA held that '[s]ection 7(8) ... creates a mechanism in terms of which the Pension Fund of the member spouse is statutorily bound to effect payment of the portion of the pension interest (as at the date of divorce) directly to the non-member spouse'. ${ }^{4}$ According to Jeram 'it is still necessary to obtain an order in terms of $\mathrm{s} 7(8)$ of the Divorce Act 70 of 1979 (the Divorce Act), if the fund is to be co-opted into payment of any assigned pension interest and the SCA ruling does not alter that position'. ${ }^{45}$ One thing that seems to be clear regarding section $7(8)$ of the DA is that there are considerations of convenience and efficiency associated with it. On the one hand, the court is empowered to direct a particular retirement fund to make payment to the nonmember spouse if sufficient facts relating to such retirement fund have been provided to the court in the pleadings. On the other hand, once an order has been adequately made in terms of this provision, it will be clear to the retirement fund as to the exact portion of the pension interest that must be paid to the non-member spouse. In Sempapalele $v$ Sempapalele and Another, ${ }^{46}$ the court was of the view that enough facts must be placed before the court in order for the court to make a decision relating to the sharing and splitting of the pension interest.

It appears that there is general consensus that at the end of the day, the divorce decree must be able to direct the retirement fund to act in a particular way. In actual fact, the Pension Funds Adjudicator has determined that it will be "sufficient if it is clear from the divorce order that a specific percentage or amount of the pension interest is assigned or due to the non-member spouse. ${ }^{47}$ On this reasoning, it is not necessarily important for the name of the retirement fund to be included in the divorce decree. All that is important, it seems, is for the retirement fund to be identifiable from the divorce decree and an indication to be made as to the portion of the member spouse's pension interests that must be paid to the non-member spouse. In other words, on this interpretation, a retirement fund which is totally silent on the pension

$44 \quad$ Ndaba supra $\mathrm{n} 8$ at par 28

45 Supra $n 15$ at 24.

4620012 SA $306(\mathrm{O})$.

47 Barnard supra n34 at par 60. See also South African Law Reform Commission '1995 Report on the sharing of pension benefits on divorce' 12-13 which submitted that A share of the pension interest of a member spouse is not to be awarded to the non-member spouse without more ado. It entails a consideration of various factors some of which may only be established by evidence. Sufficient facts must be put before the Court to enable it to arrive at a proper decision and indeed to make an appropriate award, which need not necessarily be half the value of the pension interest. At the very least the value of the pension interest must be furnished'. This suggestion was implemented by the insertion of section 7(8) into the DA. 
interest is unenforceable. Unfortunately, in practice, due to the reasons advanced above ${ }^{48}$ there are divorce decrees that are silent not only on the names of the retirement funds but the percentage or amount that must be paid to the non-member spouse. On this interpretation, it appears as if, the non-member spouse would end up being forced to apply for the variation of the divorce order in order to get a divorce order that complies with section 7(8) of the DA. For as long as section 7(8) of the DA is in operation, non-member spouses would continue to be frustrated with the legal processes by retirement funds.

The basis of my argument is that there should be some legislative framework that empowers retirement funds to accept divorce decrees that either do not reflect their names or do not state the percentage of the pension interest that must be paid to the non-member spouse. The quantification of the portion that must be paid to the non-member spouse will not be entirely challenging when the parties are married in community of property. The retirement funds actuaries may treat such divorce decrees as providing for blanket division of joint estates, unless they provide otherwise. The non-member spouse maybe paid half of the amount which the member spouse would have been eligible to receive had he or she exited the retirement fund on the date of divorce. However, difficulties relating to the quantification of the pension interest if the divorce decree is silent on the percentage or amount that must be paid to the non-member spouse will arise if the parties were married in community of property with the application of the accrual system. Under such circumstances, the amount due to the non-member spouse will depend on the calculation of the accrual as at the date of divorce. This will take into account all the assets which will be part of the accrual calculation. Given the fact that the accrual should be determined at date of divorce, it follows therefor that the pension interest should be determined at same date. ${ }^{49}$ If the pension interest was specifically excluded from the accrual determination in the parties' antenuptual contract, then the retirement fund will not have to make payment. However, if it was not excluded, then given the fact that on the date of divorce in terms of section $7(7)$ of the DA the pension interest was deemed to be an asset in the estate of the member spouse, it is submitted that when determining the accrual, the court ought to take the pension interest into account. If the value of the pension interest is taken into account in the determination of the accrual, then the member spouse would have a claim to the extent to which the member's pension interest increased the member's estate in accordance with the formula provided for in section 3(1) of the Matrimonial Property Act. It is worth noting that such a claim does not arise automatically but will only arise if the nonmember spouse's estate is smaller than that of the member spouse.

48 See the discussion in par 3.1 of this paper.

49 See generally $W v W(46463 / 2007)$ [2010] ZAGPPHC 587 (24 February 2010). 
During divorce proceedings information is placed before the court which enables it to objectively determine the accrual. ${ }^{50}$ In particular, the court is able to determine the percentage which must be paid to the nonmember spouse after a thorough assessment of all the assets and calculations arising therefrom. ${ }^{51}$ Without such calculations and subsequent court order, it will be impossible for retirement funds to ascertain exactly what should be paid to non-member spouses. As such, the argument that has been made that retirement funds on presentation of divorce decrees of parties married in community of property that are silent on both their names and percentages that must be paid cannot be sustained when parties are married subject to the accrual system. Under such circumstances, courts should be provided with sufficient information including the value of the member's pension credit in order to properly calculate the accrual and determine a percentage or amount which must be paid to the non-member spouse from the member's pension interest. It is always advisable for anyone who is contemplating divorce generally and those married out of community of property with the application of the accrual system in particular to seek legal advice in order to protect their rights. Such legal assistance should ensure that pension interests once deemed to be part of the member spouses estate are taken into account in the calculation of the accrual, unless if specifically excluded from the application of the accrual in the antenuptial contract.

$50 N v G$ and Others (18159/2013) [2018] ZAWCHC 29 (12 March 2018) para 15 where the court was of the view that '... it is evident when one considers the provisions of chapter I of the Matrimonial Property Act as a whole that the legislature contemplated a system of accrual determined by objective criteria, save where the parties might otherwise contractually agree - for example by agreeing that an inheritance should be included in the calculation of an accrual, rather than excluded as is the default position in terms of s 5 . The accrual system as provided for in terms of the chapter works on the basis set out in ss 2-5 of the Act. Section 4 provides in general terms that ' $[\mathrm{t}]$ he accrual of the estate of a spouse is the amount by which the net value of his estate at the dissolution of his marriage exceeds the net value of his estate at the commencement of that marriage'. Its more specific provisions provide for what is ordinarily to be included in or left out for the purposes of determining the accrual and how the effect of inflation is to be accommodated in calculating the accrual. The respective net values at the commencement and dissolution of the marriage are matters of objective fact, not matters to be determined by agreement. It is not open to the parties by means of a declaration to invent the objectively determinable facts by declaring or stating fictitious values. The way in which they are entitled by agreement to alter the ordinary operation of the accrual system is by excluding or including specified types of assets that ordinarily would be included or excluded in terms of the statute for the purpose of determining the respective accruals; not by misrepresenting or misstating the objectively determinable commencement values'.

51 See BS v PS (291/2017) [2018] ZASCA 37 (28 March 2018) at par 3(c). 


\section{Conclusion}

This paper demonstrated the practical challenges experienced by nonmember spouses when their divorce decrees are declared by retirement funds to be non-compliant with relevant statutory provisions. In particular, it was shown that if divorce decrees do not properly reflect the retirement funds which should make payment, non-member spouses are forced to approach divorce court in order to amend divorce decrees in order to comply with section 7(8) of the DA. It is crucial that the law is sensitive to the practical realities that litigants are faced with during the process of divorce. It is unfortunate that in practice retirement funds will be prepared to make payment only when the divorce order instructs them to do in terms of section 7(8) of the Divorce Act. It was argued that this should not be the case only in relation to marriages in community of property. In that there appears to be no need for retirement funds to refuse to pay portions of members' pension interests to the non-member spouses solely on the basis that they were not ordered to do so in terms of section 7(8) of the DA. the Pension Funds Adjudicator has determined that "the requirement that there should be a specific order to pay the nonmember spouse is contrary to the intention of the Legislature which is to remove some of the hardships that the non-member spouse experience when claiming her/his portion of the pension interest. ${ }^{52}$

52 Barnard supra $\mathrm{n} 34$ at par 60. 